\title{
An investigation on the effects of debt, firm size and liquidity on sensitivity of investment-cash flow: A case study of Tehran Stock Exchange
}

\author{
Abbas Ali Pouraghajan and Fatemeh Zabihi*
}

Department of Accounting, Mazandaran Science and Research Branch, Islamic Azad University, Sari, Iran

\section{H R O N I C L E}

Article history:

Received January 10, 2013

Received in revised format

10 April 2013

Accepted 12 May 2013

Available online

May 142013

Keywords:

Sensitivity of investment-cash flow

Debt ratio

Firm size

\section{A B S T R A C T}

This paper investigates the effects of debt, firm size and liquidity on internal resources as well as investment expenses on 140 selected firms listed on Tehran Stock Exchange over the period of 2006-2010. The survey has performed based on panel data analysis and the proposed model uses Husman model chooses random effect as well as fixed effect to analyze the data. The results indicate that there was a positive relationship between firms' debt and sensitivity of investment-cash flow. There are also some positive and meaningful relationship between firms' size and liquidity on one side and sensitivity of investment-cash flow.

\section{Introduction}

Managing financial resources plays important role on building profitable organizations and there are literally various studies associated with different factors influencing performance of organizations. Childs et al. (2005) examined relationship between flexible financing and investment decisions in a model with stockholder-bondholder conflicts over investment policy. They reported that financial flexibility could encourage the choice of short-term debt thereby dramatically reducing the agency expenditures of under-and over investment. Nevertheless, the reduction in agency expenditure might not encourage the business units to increase leverage, since the firm's initial debt level choice depends on the type of growth options in its investment opportunity set. According to Cohen and Klepper (1996) there are different evidences within industries, which indicate that the propensity to perform R $\& \mathrm{D}$ and the amount of $\mathrm{R} \& \mathrm{D}$ conducted by performers are associated with the size of the firm, while $\mathrm{R} \& \mathrm{D}$ productivity declines with firm size. These findings indicate that there is no benefit to large firm size in conducting $\mathrm{R} \& \mathrm{D}$.

Corresponding author.

E-mail: zabihi_fatemeh@ymail.com (F. Zabihi)

(C) 2013 Growing Science Ltd. All rights reserved. doi: $10.5267 / \mathrm{j} . \mathrm{ms} 1.2013 .05 .017$ 
Cohen and Klepper (1996) demonstrated how a simple model based on the concept of R \& D expenditure spreading could explain the prior findings about the R \& D-firm size relationship, as well as additional features of the $\mathrm{R} \& \mathrm{D}$-firm size relationship, denoting an advantage to large size in $\mathrm{R} \&$ D. Connolly and Hirschey (2005) reported some significant market value effects R\&D were generally apparent, but aggregate evidence had the potential to obscure meaningful differences based on firm size and their results were somewhat consistent with Fishman and Rob (1999). Estrada and Vallés (1998) perform an empirical investigation on investment and financial structure in Spanish manufacturing companies.

Fagiolo and Luzzi (2006) tried to find out whether liquidity constraints matter in explaining firm size and growth or not by looking into some evidence from the Italian manufacturing industry. They concluded that financial constraints could assist in better describing the relationship between firm growth and age, conditional on size. They also reported that size distributions depart from lognormality, and growth rates were well approximated by Laplace densities.

According to Fazzari et al. (1998) many practical techniques of investment depend on the assumption that firms were able to respond to prices set in centralized securities markets through the "cost of capital" or "q". An alternative technique implies the relative importance of cash flow as a determinant of investment spending, because of a "financing hierarchy", in which internal finance had important cost advantages over external finance. They performed an investigation on imperfections in markets for equity and debt and reported that some firms could not have enough access to external capital markets to help them respond to changes in the capital expenses, asset prices, or tax-based investment incentives. To the extent that firms were constrained in their ability to raise funds externally, investment spending could be sensitive to the availability of internal finance. They reported that $\mathrm{q}$ values remained very high for significant amount of time for companies paying no dividends, relative to those for mature firms. They also detected that investment was more sensitive to cash flow for the group of firms that their model implied was most likely to face external finance constraints.

Galeotti et al. (1994) studied the consequences of imperfect substitutability between internal and external sources of finance for firms' real decisions. The relationship between financial variables and investment when capital markets were imperfect was analyzed at both the theoretical and empirical levels based on two panels of individual Italian companies. Under the hypothesis that the firm incurs expenses of agency and financial distress, they derived both a $\mathrm{Q}$ and a Euler equation model for investment, which were then estimated together with a more loosely specified investment equation. The empirical results provided some good support for a significant departure from the hypothesis of perfect substitutability between internal and external sources of finance.

Ghosal and Loungani (1996) studied the response of investment to changes in uncertainty about future profits and realized that in industries dominated by small firms, an increase in uncertainty about future profits depresses investment; in all other industries, increased uncertainty had practically no impact on investment. Hennessy (2004) demonstrated that underinvestment stems from truncation of equity's horizon at default and reported that a statistically significant debt overhang impact regardless of firms' ability to issue additional secured debt.

Kadapakkam et al. (1998) examined the degree in which cash flow availability impacts firm investment in six OECD countries. They reported that the amount of corporate investment was influenced by internal resources in all six countries, which means, internal financing influences firm investment. They also reported that the cash flow-investment sensitivity was generally higher large firm size group and smaller in the small firm size group. De Miguel and Pindado (2001) tried to find determinants of capital structure in a survey among Spanish panel data. The results highlighted the fact that the transaction expenditures borne by Spanish firms were inferior to those borne by US firms. Finally, Worthington and West (2001) studied the usefulness of economic value-added (EVA) and its components in the Australian context. 


\section{The proposed method}

The proposed study of this paper considers the following three hypotheses,

1. There is a relationship between firm's debt and sensitivity of investment-cash flow.

2. There is a relationship between firm's size and sensitivity of investment-cash flow.

3. There is a relationship between firm's liquidity and sensitivity of investment-cash flow.

The study is performed on 140 selected firms listed on Tehran Stock Exchange over the period of 2006-2010. In our study, we use the following relationship to measure investment of firm $i$ on period $t$,

$I_{i t}=\Delta F A+D A_{i t}$,

where $\triangle F A$ and $D A$ represent change in fixed assets and depreciation on tangible and intangible assets, respectively.

In addition, cash flow $(\mathrm{CF})$ is calculated as follows,

$C F_{i t}=N P_{i t}+D A_{i t}$.

The proposed study of this paper uses Eqs. (3-5) to examine three hypotheses of the survey,

$\mathrm{I}_{\text {it }}=\mathrm{a}_{0}+\mathrm{a}_{1} \mathrm{CF} \mathrm{it}_{\mathrm{it}}+\mathrm{a}_{2} \mathrm{DLT}_{\text {it }}+\varepsilon_{\text {it }}$,

$\mathrm{I}_{\mathrm{it}}=\mathrm{a}_{0}+\mathrm{a}_{1} \mathrm{CF}$ it $+\mathrm{a}_{2} \mathrm{SIZE}_{\text {it }}+\varepsilon_{\text {it }}$,

$\mathrm{I}_{\text {it }}=\mathrm{a}_{0}+\mathrm{a}_{1} \mathrm{CF} \mathrm{it}_{\text {it }}+\mathrm{a}_{2} \mathrm{CS}_{\mathrm{it}-1}+\mathrm{a}_{3} \mathrm{LA}_{\mathrm{it}-1}+\varepsilon_{\text {it }}$

where $D L T$ and SIZE represent long term liabilities and size of firm, respectively. In addition, $C S$ and $L A$ are cash share and liquidity assets of firm, respectively. Finally, $a_{0}, a_{1}$ and $a_{2}$ represent the estimated coefficients of regression function and $\varepsilon$ is the residuals. We first use $F$ value to see whether fixed or variable effects. Table 1 demonstrates the results of our findings,

\section{Table 1}

The summary of $\mathrm{F}$ value for testing three hypotheses

\begin{tabular}{lcccc}
\hline Model & $\mathrm{F}$ & $\mathrm{df}$ & $\mathrm{p}$-value & Method used \\
\hline 1 & 6.9925 & $(139 \cdot 558)$ & 0.0000 & Fixed effect \\
2 & 6.9332 & $(139 \cdot 558)$ & 0.0000 & Fixed effect \\
3 & 5.3219 & $(139 \cdot 557)$ & 0.0000 & Fixed effect \\
\hline
\end{tabular}

As we can observe from the results of Table 1, we need to use fixed effect for regression analysis. We have also performed Hausman test to verify the fixed effect method and the results are summarized in Table 2 as follows,

\section{Table 2}

The summary of Hausman test for testing fixed effects

\begin{tabular}{lcccc}
\hline Model & Chi-Square & df & p-value & Method used \\
\hline 1 & 13.0340 & 2 & 0.0015 & Fixed effect \\
2 & 6.5655 & 2 & 0.0375 & Fixed effect \\
3 & 37.3209 & 3 & 0.0000 & Fixed effect \\
\hline
\end{tabular}

The results of the implementation of Hausman test also confirm that we need to use fixed effect method. 


\section{The results}

In this section, we present details of our findings on performing regression techniques on Eqs. (3-5).

\subsection{The first hypothesis: the relationship between debt and sensitivity of investment-cash flow}

The first hypothesis of this study investigates whether there is any relationship between firm's debt and sensitivity of investment-cash flow. Table 3 summarizes the results of our survey as follows,

Table 3

The results of regression analysis

\begin{tabular}{cccc}
\hline Variables & Coefficient & t-statistics & Prob. \\
\hline C & 0.041264 & 31.53596 & 0.0000 \\
CF & 0.011199 & 4.108573 & 0.0000 \\
DLT & 0.029175 & 2.221815 & 0.0267 \\
R-squared & & 0.635007 & \\
Adjusted R-squared & & 0.542777 & \\
F-Statistics & & 6.885074 & \\
Prob(F-statistic) & & 0.000000 & \\
Durbin-Watson & & 2.238757 & \\
\hline
\end{tabular}

As we can observe from the results of Table 3, all t-student values are meaningful when the level of significance is five percent. Durbin-Watson ratio is within acceptable limit, which means there is no auto-correlation among residuals. In addition, adjusted R-Square is equal to 54\%, which means the independent variables could explain $54 \%$ of the changes on dependent variable. Therefore, we can confirm the first hypothesis of this survey.

\subsection{The second hypothesis: the relationship between size and sensitivity of investment-cash flow}

The second hypothesis of this study investigates whether there is any relationship between firm's size and sensitivity of investment-cash flow. Table 4 summarizes the results of our survey as follows,

\section{Table 4}

The summary of the results of regression analysis for the second hypothesis

\begin{tabular}{lccl}
\hline Variables & Coefficient & t-statistics & Prob. \\
\hline $\mathrm{C}$ & 0.041346 & 31.83867 & 0.0000 \\
$\mathrm{CF}$ & 0.015492 & 4.384869 & 0.0000 \\
$\mathrm{MC}$ & 0.003137 & 1.952775 & 0.0513 \\
R-squared & & 0.653406 & \\
Adjusted R-squared & & 0.565826 & \\
F-Statistics & & 7.460674 & \\
Prob(F-statistic) & & 0.000000 & \\
Durbin-Watson & & 2.256753 & \\
\hline
\end{tabular}

As we can observe from the results of Table 4, all t-student values are meaningful when the level of significance is six percent. Durbin-Watson ratio is within acceptable limit, which means there is no auto-correlation among residuals. In addition, adjusted R-Square is equal to $57 \%$, which means the independent variables could explain $57 \%$ of the changes on dependent variable. Therefore, we can confirm the second hypothesis of this survey and conclude that firm size influences sensitivity of investment-cash flow. 


\subsection{The third hypothesis: the relationship between liquidity and sensitivity of investment-cash flow}

The third hypothesis of this study investigates whether there is any relationship between firm's liquidity and sensitivity of investment-cash flow. Table 5 summarizes the results of our survey as follows,

\section{Table 5}

The summary of the results of regression analysis for the third hypothesis

\begin{tabular}{lccl}
\hline Variables & Coefficient & t-statistics & Prob. \\
\hline C & 0.031161 & 15.30039 & 0.0000 \\
CF & 0.024436 & 5.154860 & 0.0000 \\
CS1 & -0.026594 & -5.779900 & 0.0000 \\
LA1 & 0.075860 & 6.230916 & 0.0000 \\
R-squared & & 6.230916 & \\
Adjusted R-squared & & 0.507354 & \\
F-Statistics & & 6.069495 & \\
Prob(F-statistic) & & 0.000000 & \\
Durbin-Watson & & 2.248098 & \\
\hline
\end{tabular}

As we can see from the results of Table 5, all t-student values are meaningful when the level of significance is five percent. Durbin-Watson ratio is within acceptable limit, which means there is no auto-correlation among residuals. In addition, adjusted R-Square is equal to $50 \%$, which means the independent variables could explain $50 \%$ of the changes on dependent variable. Therefore, we can confirm the third hypothesis of this survey and conclude that firm's liquidity influences sensitivity of investment-cash flow.

\section{Conclusion}

In this paper, we have performed an empirical investigation to find the relationship between three financial figures of firms including debt, size and liquidity on sensitivity of investment-cash flow. The proposed study gathered the necessary information from some firms whose shares were listed on Tehran Stock Exchange and using panel data, the survey confirmed that all three variables, debt, size and liquidity, could significantly influence on sensitivity of investment-cash flow. The results of this survey are consistent with other studies, which exist in the literature.

\section{References}

Childs, P. D., Mauer, D. C., \& Ott, S. H. (2005). Interactions of corporate financing and investment decisions: The effects of agency conflicts. Journal of Financial Economics, 76(3), 667-690.

Cohen, W. M., \& Klepper, S. (1996). A reprise of size and R \& D. The Economic Journal, 925-951.

Connolly, R. A., \& Hirschey, M. (2005). Firm size and the effect of R\&D on Tobin's q. $R \& D$ Management, 35(2), 217-223.

Estrada, Á., \& Vallés, J. (1998). Investment and financial structure in Spanish manufacturing firms. Investigaciones Económicas, 22(3), 337-360.

Fagiolo, G., \& Luzzi, A. (2006). Do liquidity constraints matter in explaining firm size and growth? Some evidence from the Italian manufacturing industry.Industrial and Corporate Change, 15(1), 1-39.

Fazzari, S., Hubbard, R. G., \& Petersen, B. C. (1988). Financing constraints and corporate investment. NBER Working Paper No. 2387.

Fishman, A., \& Rob, R. (1999). The size of firms and R\&D investment. International Economic Review, 40(4), 915-931. 
Galeotti, M., Schiantarelli, F., \& Jaramillo, F. (1994). Investment decisions and the role of debt, liquid assets and cash flow: evidence from Italian panel data. Applied Financial Economics, 4(2), 121-132.

Ghosal, V., \& Loungani, P. (1996). Firm size and the impact of profit-margin uncertainty on investment: do financing constraints play a role? (No. 557).

Hennessy, C. A. (2004). Tobin's Q, Debt overhang, and Investment. The Journal of Finance, 59(4), 1717-1742.

Kadapakkam, P. R., Kumar, P. C., \& Riddick, L. A. (1998). The impact of cash flows and firm size on investment: The international evidence. Journal of Banking \& Finance, 22(3), 293-320.

De Miguel, A., \& Pindado, J. (2001). Determinants of capital structure: new evidence from Spanish panel data. Journal of corporate finance, 7(1), 77-99.

Worthington, A., \& West, T. (2001). The usefulness of economic value-added (EVA) and its components in the Australian context. Accounting, Accountability and Performance, 7(1), 73-90. 